\title{
Community Survey Report: Lekhnath 2, Rithepani
}

\author{
Lammichane A*, Devkota A, Thakuri B, Sahi D, Magar K \\ B.Sc Nursing $2^{\text {nd }}$ Year
}

College of Nursing Sciences, Gandaki Medical College, Lekhnath, Pokhara, Nepal

\author{
Keywords \\ B.Sc Nursing, Community, \\ Community diagnosis,

\section{Corresponding author} \\ Ms Anju Lammichane \\ B. Sc Nursing, 2nd Year \\ College of Nursing Sciences \\ Gandaki Medical College \\ Lekhnath, Kaski, Nepal \\ Email: kanju91@gmail.com
}

\begin{abstract}
Community diagnosis is defined as the pattern of disease in a community described in terms of the important factors which influence the pattern -King Maurice ed (1982). It is based on collection and interpretation of the relevant data such as age, sex, population distribution by social groups, vital statistics and incidence and prevalence of important diseases of the area.
\end{abstract}

As per the curriculum of Tribhuvan University, B.Sc Nursing $1^{\text {st }}$ year, we were provided an opportunity to fulfill the practicum of community health nursing in the city of seven lakes of Rithepani-2, Lekhnath, Kaski from July $17^{\text {th }}$ to Aug $11^{\text {th }} 2016$. Total population of Rithepani ward no 2 was 4529, male population was 2100 and female population was 2429 respectively. Each of the five students was assigned with ten different families for community diagnosis in order to promote the health of the individual, family and community.

The main objective of community diagnosis was to find out the health related aspects and to provide preventive, promotive curative and rehabilitative services to the individual and community as a whole.

All the findings were presented among the key members of the community. On survey total population of 50 houses was found 239, among them 126 were male population and 113 were female population. Sanitation of the community was found appropriate. Moreover immunization services among under five children was adequate. Likewise, antenatal, intranatal and postnatal care was found appropriate and effective in all the houses. This signifies that people are utilizing the all health services in an appropriate manner.

\section{INTRODUCTION}

Community diagnosis is defined as the pattern of disease in a community described in terms of the important factors which influence the pattern -King Maurice ed (1982). It is based on collection and interpretation of the relevant data such as age, sex, population distribution by social groups, vital statistics and incidence and prevalence of important diseases of the area.
As per the curriculum of Tribhuwan University, B.Sc Nursing $1^{\text {st }}$ year, we were provided an opportunity to fulfill the practicum of community health nursing in the city of seven lakes of Rithepani-2, Lekhnath, Kaski from July $17^{\text {th }}$ to Aug $11^{\text {th }} 2016$. Total population of Rithepani ward no 2 was 4529, male population was 2100 and female population was 2429 respectively. Each of the five students was assigned with ten different families for community diagnosis in order to promote the health of 
the individual, family and community.

\section{OBJECTIVES OF THE FIELD VISIT}

The main objective of community diagnosis was to find out the health related aspects and to provide preventive, promotive curative and rehabilitative services to the individual and community as a whole.

- Find out the services provided by the selected health related institutions through observation visits

- Carry out community diagnosis in the assigned community

- Communicate effectively with all concerned in providing client-centered care

- Prepare a list of the existing facilities in the community concerning environmental sanitation

- Apply the epidemiological approaches in solving the identified problems

- Carry out the responsibilities of a community health nurse in the health promotion of community people through environmental sanitation

Table 1: Plan of action

\begin{tabular}{|c|c|c|}
\hline Date & Program & Place \\
\hline $17^{\text {th }}$ July - $19^{\text {th }}$ July, 2016 & Tool orientation & College \\
\hline $17^{\text {th }}$ July - $25^{\text {th }}$ July, 2016 & $\begin{array}{l}\text { Community } \\
\text { orientation }\end{array}$ & Community \\
\hline $17^{\text {th }}$ July - 31 $1^{\text {st } J u l y, ~} 2016$ & Community map & College and community \\
\hline $19^{\text {th }}$ July - $27^{\text {th }}$ July, 2016 & Data collection & Community \\
\hline $21^{\text {st }}$ July- $31^{\text {st }}$ July, 2016 & $\begin{array}{l}\text { Data analysis and } \\
\text { interpretation }\end{array}$ & College \\
\hline $26^{\text {th }}$ July - $12^{\text {th }}$ Aug, 2016 & Home visiting & Community \\
\hline $27^{\text {th }}$ July $-7^{\text {th }}$ Aug, 2016 & Health teaching & Community \\
\hline $1^{\text {st }}$ Aug, 2016 & Data presentation & Community \\
\hline $8^{\text {th }}$ Aug, 2016 & Health action & Community \\
\hline $9^{\text {th }}$ Aug - $12^{\text {th }}$ Aug, 2016 & Follow up & Community \\
\hline $11^{\text {th }}$ Aug $-12^{\text {th }}$ Aug, 2016 & Evaluation & College and community \\
\hline
\end{tabular}

\section{RESULTS}

Table 2: Demographic variables

\begin{tabular}{lcc}
\hline Variables & Frequency (f) & Percentage (\%) \\
\hline 1. Gender & 126 & $53 \%$ \\
Males & 113 & $47 \%$ \\
Females & & \\
2. Types of family & 35 & $70 \%$ \\
Nuclear & 15 & $30 \%$ \\
Extended & & \\
3. Religion & 47 & $94 \%$ \\
Hindu & 3 & $6 \%$ \\
Buddhism & & \\
4. Caste & 20 & $40 \%$ \\
Upper caste group & 19 & $38 \%$ \\
Relatively disadvantages Janajati & 8 & $16 \%$ \\
Disadvantages Janajati & 3 & $6 \%$ \\
Dalit & & \\
5. Types of Houses & 19 & $38 \%$ \\
Kachha & 31 & $62 \%$ \\
Pakka & & \\
6. Ventilation & & \\
Well ventilated & & \\
Poorly ventilated & 36 & $72 \%$ \\
7. Latrine & 14 & $28 \%$ \\
Water Sealed latrine & & \\
8. Drainage system & & \\
Closed & & \\
Open & & \\
9. Hand washing Habits & & \\
Soap & & \\
Ash & & \\
Mud & $50 \%$ & \\
10. Treatment of water & & \\
Treated & & \\
Not treated & & \\
11. Method of purification of water & & \\
Boiling & & \\
Filter & & \\
\hline & & \\
\hline
\end{tabular}

In the data depicted in Table 2 shows more than half (53\%) of the respondents were male population whereas more than one third (47\%) were female population. Median age of population was 44 and the sex ratio was 4 : 3 male and female respectively. The dependency ratio was $28 \%$ and literacy rate was $92 \%$. Disability rate was found to be zero. Similarly, majority (70\%) of the family lives in the nuclear family. Regarding religion, majority (94\%) of the respondents are Hindus and only 6\%of respondents were Buddhist. In terms of caste, less than the half (40\%) of the respondents were of upper caste group. More than the half (62\%) of the families live in pakka type of houses. Similarly, majority (72\%) families have well ventilation and all the families were found to use water sealed latrine. In terms of drainage system, majority (82\%) of 
the families used closed drainage system. Regarding hand washing practices, majority (96\%) families use soap. Similarly majority $(84 \%)$ of the families were found to treat water before drinking and more than half $(60 \%)$ of the families drink water by filtering it.

\section{Maternal Health on Lekhnath-2, Rithepani}

Fig 1: Family planning (Eligible couples $=20)$

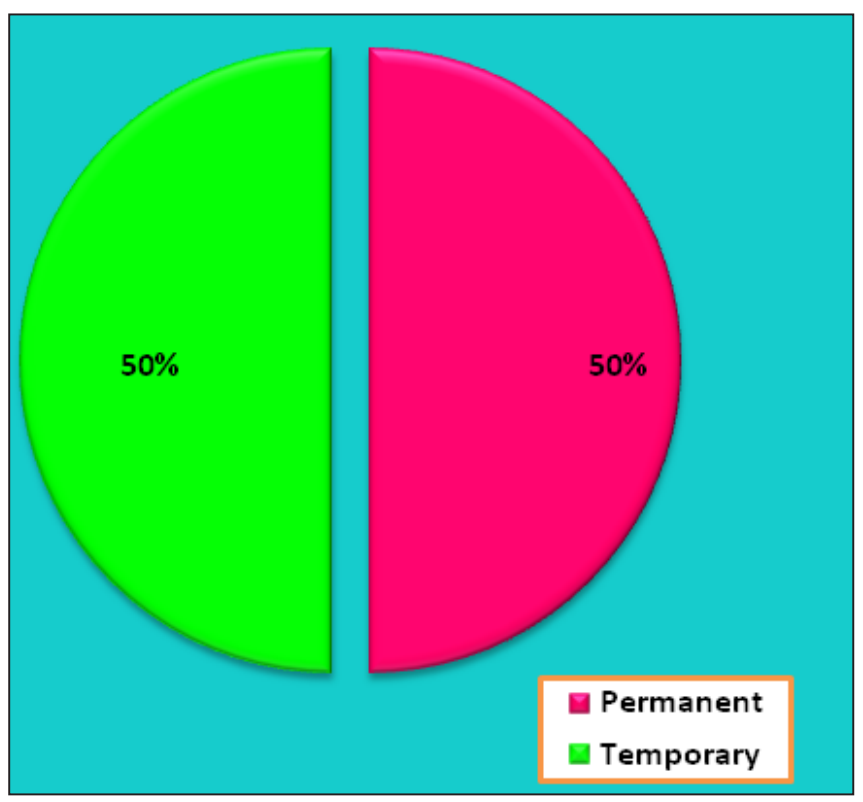

From the above pie-chart it is depicted that among eligible couples half (50\%) of the population were using permanent family planning methods whereas remaining half $(50 \%)$ were using temporary family planning methods.

All the pregnant women of the Rithepani-2 have received antenatal care services from the respected heath care institutions. And all the pregnant women had received tetanus toxoid during antenatal visit from the respected health care institutions.

Majority of the population went to health care centers during illness. Majority (92\%) of the population follow the non-vegetarian food habits. Most of the families (62\%) have separate kitchen and majority (78\%) of the families have kitchen garden in their houses. Environmental sanitation was found to be good. Majority of the houses (86\%) were found to have insects like cockroaches, mosquitoes, houseflies which clearly indicate the risk for diseases.

On the day of health action all the key members from the community, faculties from the college and community people were invited and the program was conducted in formal manner. Data presentation was done. As a health action, drama on the theme of diarrhoeal disease, alcohol addiction, smoking, care during pregnancy and postnatal period and domestic violence was conducted. Nutritional exhibition was also carried out along with real articles.

\section{Acknowledgement}

We are extremely grateful towards GMC, for providing us all the resources and facilities required for this project. This wouldn't have been possible without the continuous support and guidance by our Co-ordinator Ms. Muna Silwal. Likewise, we are thankful to our teachers Ms. Nisha Shrestha, Ms. Aditi Gurung, Ms. Rajmi Gurung and Ms. Sujata Ojha who helped us throughout the project. Moreover, we would also like to thank the Ward President, Community leaders, Female community health volunteers as well as all the community people for providing us the required information and making this project a successful one. How can we ever miss to thank the store department as well as the Information Technology Department who provided us with all the required supply. At last but not the least, we would like to thank our dear helper didi Dil Kumari Thapa for aiding us in this project.

\section{REFERENCES}

1. K. Park. Park's Textbook of Preventive and Social Medicine, 22th edition. Banarsidas publishers, Jabalpur (MP), India. 2013.

2. Basvanthappa. B.T. Community Health Nursing. Jaypee Brothers Medical Publishers Pvt. Ltd. New Delhi. India. 1998.

3. Ghimire. B. Textbook of Community Health Nursing. $4^{\text {th }}$ Edition. Heritage Publishers and Distributors P. Ltd. Bhotahity, Kathmandu. Nepal. 2015. 